\title{
TWO POSSIBLE RECORDS OF BARROW'S GOLDENEYE IN SASKATCHEWAN
}

by Robert W. Nero, Regina

Records of the Antapa Shooting Club include notes since 1929 on ducks killed on Pasqua Lake in the Qu'Appelle River system. Recently, while examining the Club records, which were kindly made available by $\mathrm{Mr}$. R. J. Balfour, secretary of the Club, I noticed references in five places to the Common Goldeneye and in one, to a Barrow's Goldeneye. Upon enquiry to Mr. Marsh Young, Regina resident who had made the notation on the Barrow's Goldeneye in the Club journal, some further information on this note on the latter species, which has not been reported for Saskatchewan, was obtained. The duck in question was shat on October 12, 1964 by Mr. Young's son Jamie Young. The duck was recognized as an unfamiliar one and was checked on that date by referring to an illustrated booklet on waterfowl identification by A. H. Shortt and B. W. Cartwright, Know your ducks and geese (1954. Reprinted from Sports A field, New York). According to Young, the duck had the characteristic features described in that guide for the adult male Barrow's Goldeneye, particularly the purple head color (rather than green as in the Common Goldeneye) and the distinctive white area between the bill and the eye.Although self-admittedly not even an amateur ornithologist Mr. Young felt certain that their identification was correct. Unfortunately, the importance of reporting the incident and verifying the identification was not recognized and no part of the duck was saved.

A more substantial record of Barrow's Goldeneye was recently brought to our attention by E. Manley Callin who has had a record of this species in his files since 1956. This was a single male sighted near Morse, Saskatchewan $(75$ miles west of Moose Jaw) on April 6, 1956 by John M. Nelson of Moose Jaw. Field notes submitted to Manley Callin on April 15, 1956 by Nelson included the following information:

"Barrow's Goldeneye (Morse)-This is my honour item. I spotted a single male on a fair-sized slough south of Morse. I managed to sneak within a very few yards of him and identifica- tion was quite positive. He didn't appear to be very wary and after watching it for some time I stood up; but he didn't appear very perturbed and didn't fly."

Before sending us this record, Manley telephoned John Nelson on June 17, 1965 and abtained the following additional details:

1. He recalled the occasion very well as it was quite an exciting incident to him.

2. He watched the bird with binoculars for varying distances, mostly at very close range, for approximately one-half hour.

3. He had his "Peterson guide" with him and had ample time to refer to details; the bird was exactly according to the book.

4. He distinctly remembered the white crescent instead of the round spot and the larger amount of black on the sides, but he did not remember whether or not the purple instead of the green gloss on the head was noted.

5 . He was still positive that it was a Barrow's Goldeneye.

Manley has noted that even in $\mathbf{1 9 5 6}$ John Nelson had been familiar with the Common Goldeneye for 20 years or more. It should further be noted that Nelson is an experienced observer who has been a regular contributor of field notes for many years.

According to the A.O.U. Check-list of North American birds (1957), Barrow's Goldeneye (Bucephala islandica) breeds in widely scattered localities from Alaska and northern Mackenzie south to California, in the mountains of Colorado, in northeastern Quebec and northern Labrador. In addition, it is listed as a fairly common resident of the mountainous area of west-central Alberta, with scattered records of migrants from Calgary to Wood Buffalo Park (Salt and Wilk, 1958, The Birds of Alberta). Not unexpectedly, it has been reported as a migrant in northern Montana and elsewhere in the interior plains, but to date there seem to be no published records for Saskatchewan or Manitoba. The value of this brief note may lie chiefly in calling attention to a species which may be of occasional occurrence in this region. 